\title{
EFFICACY AND SAFETY OF TURMERIC IN LOWERING BLOOD LIPID LEVELS AND GLUCOSE IN RATS FED HIGH-FAT DIETS
}

\author{
By \\ El-Sayeda Ghandour Elsayed El-Sahar \\ Home Economic Department. \\ Faculty of Specific Education, \\ Ain Shams University, Cairo, Egypt
}

Research Gournal Specific Fducation

Faculty of Specific Education

Mansoura University

ISSUE NO. 58, APRIL , 2020

مجلة بحوث التربية النوعية - جامعة المنصورة

العلدد الثامن والخمسوز - أبريل .r.r. 
-Efficacy and safety of turmeric in lowering blood lipid levels and glucose in rats Fed High-Fat Diets 


\title{
EFFICACY AND SAFETY OF TURMERIC IN LOWERING BLOOD LIPID LEVELS AND GLUCOSE IN RATS FED HIGH-FAT DIETS
}

\author{
El-Sayeda Ghandour Elsayed El-Sahar*
}

\section{Abstract}

Curcuma longa L. plant (known as curcum hence the name Curcuma, turmeric) is a member of the Curcuma botanical group, which is part of the ginger family of herbs, Turmeric is used worldwide as the main ingredient in curry, the spice, and as a source for curcumin or curcuminoids. it is used for medicinal purposes This study was conducted on sixty Sprague Dawley strain male rats and weighting $100 \pm 10$ g. Six rats served as control (-ve) group (Co.(-)) while Twenty-four rats were fed high- containing basal diet $+5 \%$ tallow $+1 \%$ cholesterol+ $0.02 \%$ bile salt to induce Hypercholesterolemia. These rats were reclassified into control $(+\mathrm{ve})$ (Co.(+)), three treated rat groups that were 4,6 and $8 \mathrm{~g} / \mathrm{kg}$ diet turmeric. The treatment period was designed for six weeks. The obtained results revealed that the total cholesterol (TC), triglycerides (TG), HDL-C and LDL-C were determined, in addition to serum glucose, liver and kidney function. The histopathological changes of the heart, liver and kidney were evaluated. SPSS, one way ANOVA was used to analyze the results. The results indicated that dietary curcumin significantly blocked the effect of HFD on the body-weight gain, the best value was in G (3), The best treatment was turmeric $(6 \mathrm{~g}$ and $8 \mathrm{~g})$ which had the lowest values of total cholesterol, TG and LDL-C, and the best values of HDL-C. Also, the best improvement in glucose level in G (3), results clearly revealed that the best treatment was turmeric ( $8 \mathrm{~g} / \mathrm{Kg}$ diet) which had the lowest values of ALK, ALT and ALP. uric acid and urea gave a significant decrease in groups G2 and G3. The moderate and higher dose from turmeric gave normal histological structure in the heart, liver and kidney in Morphologic changes. In conclusion, results showed that turmeric had a similar potential to

Home Economic Department.Faculty of Specific Education, Ain Shams University, Cairo, Egypt 
attenuate CHD-related parameters in mild oxidative stress induced by a high-fat diet in rats.

KEYWORDS: Atherosclerosis turmeric, Liver, Heart, High-Fat Diets rats

\section{INTRODUCTION}

Hypertension, dyslipidemia, obesity, type 2 diabetes mellitus (T2DM), and metabolic syndrome, and insulin resistance, promote endothelial dysfunction and vascular inflammation leading to atherosclerosis - the main cause of CVD (Srikanth and Deedwania 2016). The study showed that low circulating concentrations of triglycerides (TG) and low-density lipoprotein cholesterol (LDL-C) were associated with a low risk of CVD (Musunuru, 2010). Therefore, the treatment of dyslipidemia is critical for the prevention of CVD.

Turmeric (Curcuma longa), an Indian spice, is a yellow pigment that is used worldwide in cooking, cosmetics, dyes, and medicines (Goel et al., 2008). It is worth noting that turmeric is a frequently used food additive in Southeast Asia, which mends the color and flavor of food preparations. Curcumin (chemical name: diferuloylmethane) is an effective component of turmeric (Sahebkar,2013) which has the ability to interact with hundreds of molecular targets. Many studies have confirmed the protective effects of curcumin against many chronic diseases, including pulmonary disorders, various cancers, and autoimmune diseases (Kunnumakkara et al., 2016). It has been shown to attenuate oxidative stress (Pulido et al., 2016) and to exert a cardioprotective effect owing to its lipid-lowering properties (Maithilikarpagaselvi et al., 2016; Li et al., 2015 and Shin et al., 2011). Also, most of the randomized trials have reported positive effects of curcumin on blood lipid levels. Nonetheless, conflicting reports exist in that some studies have reported promising effects (Rahmani et al., 2016; Rahimi et al., 2016; Maithili et al., 2015; Amin et al., 2015; Yang et al., 2014 and Chuengsamarn et al., 2013). Whereas others failed to demonstrate any significant effect (Usharani et al., 2008). 
Turmeric is on the FDA's Generally Recognized as Safe list. No $\mathrm{LD}_{50}$ has been discovered for curcumin(Bratman and Girman 2003). Cheng et al.,(2001) found that curcumin is not toxic in oral human doses up to $8000 \mathrm{mg}$ /day for 3 months. Curcumin has a wide range of therapeutic actions as the ability to halt or prevent certain types of cancer (Aggarwal et al., 2003; Bharti et al., 2003 and Chan et al., 2003), anti-inflammation (Ramsewak et al., 2000); improve cardiovascular health (Ramirez-Tortosa et al., 1999; Quiles et al., 2002 and Mesa et al., 2003); prevent cataracts (Suryanarayana et al., 2003).

Many naturally occurring dietary polyphenols possess antioxidant and anti-inflammatory properties (Alappat and Awad, 2010). This could be achieved by modulating an inflammatory or oxidative signaling pathway, (Alappat and Awad, 2010; Yu et al., 2010 and Bereswill et al., 2010). Many dietary polyphenols, such as curcumin, also have anti-carcinogenic effects. One prospect mechanism of curcumin to suppress tumorigenesis(Mukhopadhyay, 2002 and Jaiswal et al., 2002).Curcumin, a low-molecular-weight polyphenol obtained from the herbal medicine and dietary spice turmeric, was found to suppressed obesity and diabetes in rats models (Weisberg et al., 2008).curcumin may do its beneficial effects decrease leptin and insulin resistance, speed fatty acid oxidation, weaken inflammatory cytokine, also enhancing antioxidant enzyme (Alappat and Awad, 2010).

In addition, curcumin could also function as an inhibitor of p300 histone acetyltransferase (HAT), a potential molecular mechanism for cancer prevention and cardiovascular improvement (Morimoto et al., 2008 and Barnes, 2009). (Alappat and Awad, 2010). In addition, curcumin could also function as an inhibitor of p300 histone acetyltransferase (HAT), a potential molecular mechanism for cancer prevention and cardiovascular improvement (Morimoto et al., 2008 and Barnes, 2009). It is to focus efforts toward improving the most effective drugs and exploring natural factors as alternatives to the treatments that are currently available. 
This study aimed to investigate the effects of turmeric on blood lipids level and glucose in a rat model with mild oxidative stress induced by a high-fat diet.

\section{MATERIALS AND METHODS:}

\section{Animals protocols:}

Thirty male Sprague Dawley rats, weighing $100 \pm 10 \mathrm{~g}$ were used in this study. They were obtained from the National Research Center (NRC) Dokki Giza Egypt. Animals were clinically healthy and they randomized and housed in stainless steel wire bottom cages (3 rats /cage) and maintained in an air-conditioned room on a $12 \mathrm{~h}$ light/ dark cycle at $22+2$ ${ }^{\circ} \mathrm{C}$ and given the basal diet for 10 days as an adaptation period before treatments.

\section{Preparation of turmeric}

Turmeric was purchased from the local market as roots, then grounded before mixing with the diet and added to the basal diet in $4 \mathrm{~g}, 6 \mathrm{~g}$ and $8 \mathrm{~g} / \mathrm{kg}$ diet. During the feeding experiments, animals were daily inspected and food intake was recorded while body weights were recorded according to (Chapman et al., 1959). The feeding experiment lasted for six weeks.

Tallow was purchased from the local market, then grounded before mixing with the diet and added to the basal diet in $50 \mathrm{~g} / \mathrm{kg}$ diet.

\section{Experimental design}

The animals were distributed into two main groups: the first, negative control group Co. (-) $(\mathrm{n}=6)$, fed basal diet (AIN, 1993). The second group $(\mathrm{n}=24)$ fed high- fat diet (containing basal diet $+5 \%$ tallow $+1 \%$ cholesterol $+0.02 \%$ bile salt). This group was divided into four subgroups: group positive control co. (+) (n=6) fed high-fat diet only, group 1 (G (1)) $(\mathrm{n}=6)$ fed high-fat diet plus $4 \mathrm{~g} / \mathrm{kg}$ diet turmeric, group 2 ( $\mathrm{G}(2)(\mathrm{n}=6)$ fed high-fat diet plus $6 \mathrm{~g} / \mathrm{kg}$ diet turmeric, and group $3(\mathrm{G}(3))(\mathrm{n}=6)$ fed highfat diet plus $8 \mathrm{~g} / \mathrm{kg}$ dietturmeric. 
$\overline{\underline{ }}$ r.r. مجلة بحوث التربية النوعية- عدد Aه - أبريل

\section{Used chemicals}

Cholesterol as pure white crystalline powder and bile salts as a pure yellow powder were obtained from Elgamhoria Company for Med Preparations Chemicals and Medical Equipment's, Cairo -Egypt.

\section{Biological evaluation}

During the experimental period (6 weeks), the diet consumed was recorded every day. The body weight gain (B.W.G \%) and feed efficiency ratio (F.E.R.) were determined according to Chapman et al. (1959).

At the end of the experiment period, animals were sacrificed after 12 $\mathrm{h}$ of fasting then blood samples were collected with care to avoid hemolysis by receiving it on the wall of the tube. Blood samples were collected in clean dry labeled centrifuge tubes and left to clot at room temperature for a while, then centrifuged at $3000 \mathrm{rpm}$ for 10 minutes. The clear supernatant serums were aspirated by means of Pasteur pipette and stored at $-20^{\circ} \mathrm{C}$ in Epindorff's tubes until used in the biochemical analysis (Drury and Wallington, 1980).

Serum total cholesterol (TC), triglycerides (TG), high-density lipoprotein cholesterol (HDL-C) and low-density lipoprotein cholesterol (LDL-C) were determined by using enzymatic colorimetric method (NIHP, 1987; Young and Pestaner, 1975; Fendewaid, 1972; Gordon and Amer, 1977; Lee and Nieman, 1996), respectively. Very low-density lipoprotein cholesterol (VLDL-C) was carried out according to Lee and Nieman (1996) as follows VLDL-C $=\mathrm{TC}-(\mathrm{HDL}-\mathrm{c})$ - $(\mathrm{VLDL}-\mathrm{c})$.

Serum activities of aspartate aminotransferase AST, alanine aminotransferase ALT Alkaline Phosphatase (ALP) activities were colorimetrically determined according to the method described by Reitman and Frankel (1957). Uric acid, Serum urea nitrogen and creatinine were determined consistent with the methods described by Fossati et al., (1980), Patton and Crouch, (1977) and Husdan and Rapoport, (1968). Serum total protein and creatinine were determined by Henry (1964) and Reitman and Frankel (1957) respectively. Albumin content was calculated from the 
standard curve prepared by sub dilution preparation of the albumin stock and the corresponding absorbencies.

\section{Sample preparation}

The target organs were examined as follows: Organs such as heart, liver and kidney were excised and weighed. Then washed in cold saline ( 9 $\mathrm{g} / \mathrm{l} \mathrm{NaCl}$ ), stored in formalin solution (10\%) for $24 \mathrm{r}$ hours. Washing was wiped out the water then serial dilutions of alcohol (methyl, ethyl and absolute ethyl) were used for dehydration. Specimens were cleared in xylene and embedded in paraffin at 56 degrees in a hot air oven for 24 hours. Paraffin bees wax tissue blocks were prepared for sectioning at four microns by slide microtome. The obtained tissue sections were collected on glass slides, deparaffinized and stained by hematoxylin and eosin stains (Bancraft et al., 1975) for histopathological examination through the microscope.

\section{Statistical Analysis}

Statistical Analysis was performed by using the computer program, Statistical Package for Social Sciences (SPSS, 1998). Values are given as means $\pm \mathrm{SD}$, and the differences between groups were determined by one way ANOVA. Values of $P<0.05$ were considered significant.

\section{RESULTS AND DISCUSSION:}

\section{Effect of turmeric:}

\section{1- Bodyweight gain, food intake and feed efficiency ratio.}

As shown in Table .1, the mean values of initial body weight (IBW) of all experimental groups (G1, G2 and G3) showed no significant difference when compared with Co. $(+)$. The mean value of final body weight $(\mathrm{FBW})$ in group Co. $(+)(154.80 \pm 18.67 \mathrm{~g})$ was significantly $(\mathrm{p}<0.05)$ higher compared to the corresponding mean values of groups Co. (-), G 1, G 2 and G3 (116.60 $\pm 27,95.00 \pm 16.87,85.20 \pm 20$, and 91.60 \pm 17.53 respectively). The mean values of body weight gain (BWG) and feed efficiency ratio (FIR) in groups Co. (-), G 1, G 2 and G3 had significant 
decrease when compared with group co (+), while G (2) and G (3) showed highest significant decrease compared to group co (-) and co. (+).

This result agreed with, Ghada and Soliman (2005) who revealed that body weight gain (BWG) of curcumin in the treated groups showed a slightly non-significant decrease in their BWG than control. Also, FBW and BWG of cholesterol-fed rats were significantly higher than that of their respective control group. Which are in agreement with Hulbron et al. (1982) and disagree with Sérougne et al. (1995).

Also, Shao et al. (2012)confirmed that Long term dietary curcumin administration blocked HFD-induced body-weight gain and obesity in chronic HFD mouse model, body-weight increased significantly only after 16 weeks of HFD feeding. At the end of the 28th week, dietary curcumin significantly blocked the effect of HFD on body-weight gain. HFD also significantly increased a load of epididymal fat pads, while curcumin supplementation significantly blocked this stimulation. Oral curcumin supplementation was shown to stop the event of obesity-associated inflammation(Weisberg et al., 2008).

Table (1): Body weight gain, food intake and feed efficiency ratio after 6 weeks feeding.

\begin{tabular}{|c|c|c|c|c|c|}
\hline Groups & $\operatorname{IBW}(\mathrm{g})$ & $\operatorname{FBW}(\mathbf{g})$ & BWG (g) & FI $(g)$ & FER\% \\
\hline Co.(-) & $106.20^{b} \pm 24.14$ & $116.60^{c} \pm 27.37$ & $10.40^{\mathrm{b}} \pm 3.44$ & $16.20^{c} \pm 1.10$ & $0.64^{b} \pm 0.22$ \\
\hline Co. $(+)$ & $97.60^{\mathrm{a}} \pm 22.17$ & $154.80^{b} \pm 18.67$ & $57.20^{\mathrm{a}} \pm 4.82$ & $19.80^{\mathrm{ab}} \pm 1.92$ & $2.91^{\mathrm{a}} \pm 0.41$ \\
\hline G1 & $99.00^{\mathrm{a}} \pm 17.90$ & $95.00^{\mathrm{ab}} \pm 16.87$ & $-4.00^{c} \pm 1.87$ & $21.00^{\mathrm{a}} \pm 2.45$ & $-0.19^{c} \pm 0.09$ \\
\hline G2 & $98.20^{\mathrm{a}} \pm 13.48$ & $85.20^{b} \pm 20.00$ & $-13.00^{\mathrm{c}} \pm 14.44$ & $18.00^{\mathrm{bc}} \pm 2.00$ & $-0.69^{c} \pm 0.71$ \\
\hline G3 & $105.80^{\mathrm{a}} \pm 19.95$ & $91.60^{\mathrm{ab}} \pm 17.53$ & $-14.20^{c} \pm 5.97$ & $21.40^{\mathrm{a}} \pm 1.52$ & $-0.66^{c} \pm 0.25$ \\
\hline
\end{tabular}

Co (-), normal diet; Co (+) high-fat diet; G(1), high-fat diet plus turmeric (4g); G (2), high-fat diet plus turmeric $(6 \mathrm{~g}) ; \mathrm{G}(3)$, high-fat diet plus turmeric (8 g); IBW, initial body weight; FBW, final body weight; BWG, body weight gain; FI, food intake; FER, feed efficiency ratio. Values with the same letters by column indicate no significant difference $(\mathrm{p}<0.05)$ and vice versa. 


\section{2- Relative weight of heart, liver and kidney:}

The results showed that in groups (G1, G2 and G3) fed on a high-fat diet and turmeric the relative weight of the heart and liver had a significant increase when compared with control negative group. However kidney weight had no significant difference in G1 when compared with the control positive group, However, relative kidney weight showed a significant increase in G2 and G3 $(0.79 \pm 0.09$ and $0.87 \pm 0.14)$ when compared with group co.(+). (Table .2). This result agrees with Ghada and Soliman (2005) demonstrated that relative liver and heart weight of cholesterol-fed groups showed a significant increase when compared with the control group. The significant increase in liver and heart weight may be attributed to fat deposits. As recorded by several investigators, increased cholesterol level increases the fat accumulation in the liver (Kahloneet al. 1997 and Murray et al. 2000).

Table (2): Relative weight of heart, liver and kidney (g):

\begin{tabular}{|c|c|c|c||}
\hline Groups & Heart (g) & Liver (g) & Kidney (g) \\
\hline \hline Co.(-) & $0.30^{\mathrm{c}} \pm 0.07$ & $2.56^{\mathrm{b}} \pm 0.59$ & $0.74^{\mathrm{b}} \pm 0.21$ \\
\hline Co.(+) & $0.33^{\mathrm{b}} \pm 0.06$ & $2.92^{\mathrm{a}} \pm 0.82$ & $0.73^{\mathrm{a}} \pm 0.11$ \\
\hline G1 & $0.32^{\mathrm{ab}} \pm 0.09$ & $2.88^{\mathrm{a}} \pm 0.72$ & $0.73^{\mathrm{a}} \pm 0.12$ \\
\hline G2 & $0.31^{\mathrm{b}} \pm 0.06$ & $2.93^{\mathrm{a}} \pm 0.32$ & $0.79^{\mathrm{a}} \pm 0.09$ \\
\hline G3 & $0.33^{\mathrm{ab}} \pm 0.04$ & $2.78^{\mathrm{a}} \pm 0.68$ & $0.87^{\mathrm{a}} \pm 0.14$ \\
\hline
\end{tabular}

Co (-), normal diet; Co (+) high-fat diet; G(1), high-fat diet plus turmeric (4g); G (2), high-fat diet plus turmeric $(6 \mathrm{~g}) ; \mathrm{G}(3)$, a high-fat diet plus turmeric (8 g). Values with the same letters by column indicate no significant difference $(\mathrm{p}<0.05)$ and vice versa.

\section{3- Serum lipid profile and glucose level:}

Table (3) shows the effect of different levels of turmeric on serum total cholesterol (TC), triglyceride (TG), low-density lipoprotein cholesterol (LDL-C) and high-density lipoprotein cholesterol (HDL-C). It could be observed that group co. (+) had a significant increase in TC, TG and LDL-C compared with control negative rats. Also, all groups fed on high-fat diet containing different levels of turmeric $(4,6$ and $8 \mathrm{~g} / \mathrm{kg}$ diet) had significant 
decrease in TC, TG and LDL-C compared with control positive group of rats, also could be observed that G2 and G3 fed on high-fat diet containing levels of turmeric ( 6 and $8 \mathrm{~g} / \mathrm{kg}$ diet) had improved significantly in HDL-C

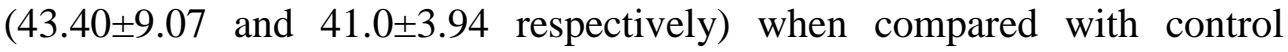
positive group co. (+). The groups fed on turmeric give results similar to group co. (-). The best treatment was turmeric $(6 \mathrm{~g}$ and $8 \mathrm{~g})$ which had the lowest values of total lipid cholesterol, TG and LDL-C, and the best values of HDL-C. However, the results demonstrated that the mean values of glucose had a significant decrease in groups fed on a high-fat diet containing different levels of turmeric $(4 \mathrm{~g}, 6 \mathrm{~g}$ and $8 \mathrm{~g} / \mathrm{kg}$ diet)when compared with control positive group co. $(+)$.

This result agreed with Ghada and Soliman (2005) who indicated that serum cholesterol (total, LDL, VLDL) of the groups of normal rats which fed on curcumin- or curcum was significantly lower than the control group. Also serum HDL-C of groups of curcumin- /or curcum- fed was significantly above the control group. An identical result's found in hypercholesterolemic rats which ate up different levels of curcuminand/or curcum.

Also, founded this review which identified 7 trials of turmeric and curcumin in patients in danger for disorder evidence of their beneficial effects on serum levels of LDL-C and TG, although there was no significant difference in HDL levels within the blood. A beneficial effect of turmeric and curcumin on serum TC levels has been observed in people with metabolic syndrome; however, in people with high blood sugar, this beneficial effect on serum TC levels has not been observed. The natural form (turmeric) and curcumin appear to have more positive effects on patients with metabolic syndrome. Related to the forms of interference, turmeric extract may have a better beneficial effect on TC levels in the blood, compared to concentrations of turmeric in its natural form (Si et al., 2017).

Sahebkar,(2013) conducted the effects of curcumin on blood lipid levels and found no significant improvements in the lipid profile in any 
aspect. Several explanations could be tendered to explain why the results of their study were contrary to those of the present study. Firstly, both parallel and crossover randomized trials were selected, and these may have adversely influenced the ultimate results. The effect of low-dose and moderate-dose curcumin slightly lowers the total cholesterol, In the case of the curcumin effect on LDL cholesterol level, the low-dose has demonstrated the highest decrease $(-8.6 \%)$, followed by the moderatedose $(3.4 \%)$ and therefore the worst effect has been demonstrated within the high-dose, i.e. an increase by $15.4 \%$. However, it was not significantly different when compared to the placebo (Alwi et al., 2008).

Secondly, most of the selected studies were conducted with unformulated curcumin, which is considered to have low bioavailability. Curcumin has poor bioavailability owing to its fast metabolism, its bad absorption and rapid elimination from the body. Mohammadi et al. (2013) demonstrated the hypothesis that curcuminoids $(1 \mathrm{~g} /$ day for 30 days) lead to a significant decrease in serum TG concentrations in obese individuals. During a trial among patients with arteriacoronaria disease, although curcumin supplementation decreased serum levels of TC, LDL$\mathrm{C}$, and $\mathrm{TG}$, there was no obvious difference in comparison to placebo (Mirzabeigi et al., 2015) possibly due to the small size of the study. Subsequently, a study by Soare et al. (2014) found that $900 \mathrm{mg}$ of curcumin did not influence plasma lipid levels in non-obese relatively healthy individuals.

Babu and Srinivasan. (1997) reported a hypolipidemic effect of curcumin in streptozotocin-induced diabetic rats and fed with $0.5 \%$ curcumin for 8 weeks. The cholesterol level decreased significantly in rats fed with a curcumin diet. In order to understand the mechanism of lowering cholesterol in the curcumin diet, a measurement was taken on the activity of hepatic cholesterol-7a-hydroxylase. It was apparent that the hepatic cholesterol-7a-hydroxylase level was significantly higher in diabetic rats fed with curcumin, which demonstrated a higher cholesterol catabolism rate.Neerati and Gangi (2014) reported that curcumin could counter Insulin resistance. Through the improvement of metabolic 
disturbance and the possible binding of curcumin with peroxisome proliferator-activated receptor-gamma, curcumin could play a protective role in diet-induced insulin resistance (Jayakumar et al., 2016).

Sao et al. (2012) confirmed that Insulin was less effective in lowering the glucose level in HFD animals, while curcumin supplementation efficiently blocked this effect of HFD. These data suggest that curcumin improves whole-body glucose disposal by both stimulations of insulin sensitivity and inhibition of hepatic gluconeogenesis. Curcumin improved insulin signaling in fat and hepatocytes. Which suppressed expression of the LDL-C receptor gene, and could thereby reduce plasma LDL-C concentrations (Kang and Chen 2009). Furthermore, curcumin is expected to affect both synthesis and catabolism of triglyceride-rich lipoproteins (Sahebkar ${ }^{1}$ 2014). Thus, curcumin supplementation may lower plasma triglycerides and cholesterol concentrations by mitigating the expressions of lipogenic genes (Sahebkar 2014 and Sahebkar et al., 2014).

Si et al. (2017) found that consumption of turmeric and curcumin was safe and well-tolerated in general. And dosages as high as 8000 $\mathrm{mg} /$ day have been shown to be well-tolerated with no apparent toxicity (Cheng et al., 2001). Oral curcumin supplementation was shown to prevent the development of -associated inflammation insulin resistance, as well as diabetes (Weisberg et al., 2008). 
-Efficacy and safety of turmeric in lowering blood lipid levels and glucose in rats Fed High-Fat Diets

Table (3): Effect of turmeric on serum lipid profile and glucose in rats after 6 weeks.

\begin{tabular}{||c|c|c|c|c|c||}
\hline Groups & $\begin{array}{c}\text { CH } \\
(\mathbf{m g} / \mathbf{d l})\end{array}$ & $\begin{array}{c}\text { TG } \\
(\mathbf{m g} / \mathbf{d l})\end{array}$ & $\begin{array}{c}\text { HDL } \\
(\mathbf{m g} / \mathbf{d l})\end{array}$ & $\begin{array}{c}\text { LDL } \\
(\mathbf{m g} / \mathbf{d l})\end{array}$ & $\begin{array}{c}\text { GIU. } \\
(\mathbf{m g} / \mathbf{d l})\end{array}$ \\
\hline \hline Co.(-) & $76.00^{\mathrm{b}} \pm 15.70$ & $68.20^{\mathrm{b}} \pm 9.78$ & $48.40^{\mathrm{b}} \pm 9.74$ & $32.80^{\mathrm{b}} \pm 8.79$ & $79.20^{\mathrm{b}} \pm 9.36$ \\
\hline Co.(+) & $132.80^{\mathrm{a}} \pm 26.19$ & $124.00^{\mathrm{a}} \pm 21.71$ & $35.40^{\mathrm{a}} \pm 18.58$ & $81.20^{\mathrm{a}} \pm 4.09$ & $108.20^{\mathrm{d}} \pm 4.4$ \\
\hline G1 & $73.80^{\mathrm{a}} \pm 8.23$ & $102.20^{\mathrm{a}} \pm 7.26$ & $37.60^{\mathrm{a}} \pm 13.24$ & $52.80^{\mathrm{a}} \pm 7.19$ & $79.60^{\mathrm{b}} \pm 9.58$ \\
\hline G2 & $82.60^{\mathrm{ab}} \pm 9.29$ & $79.80^{\mathrm{a}} \pm 10.03$ & $43.40^{\mathrm{ab}} \pm 9.07$ & $34.40^{\mathrm{a}} \pm 14.29$ & $72.60^{\mathrm{bc}} \pm 2.30$ \\
\hline $\mathbf{G 3}$ & $84.80^{\mathrm{ab}} \pm 8.58$ & $72.20^{\mathrm{a}} \pm 22.81$ & $41.00^{\mathrm{a}} \pm 3.94$ & $32.40^{\mathrm{a}} \pm 8.29$ & $73.00^{\mathrm{a}} \pm 3.39$ \\
\hline \hline
\end{tabular}

Co (-), normal diet; Co (+) high-fat diet; G(1), high-fat diet plus turmeric (4g); G (2), high-fat diet plus turmeric (6g); G (3), a high-fat diet plus turmeric (8 g).Values with the same letters by column indicate no significant difference $(\mathrm{p}<0.05)$ and vice versa.

\section{4- Effect of turmeric on liver function in rats fed a high-fat diet.}

In this study, the effect of turmeric on liver function in rats after 6 weeks illustrated in the table (4). Where groups G1, G2 and G3 gave significant difference in ALT and AST when compared with control negative group, however, I found a significant decrease in ALK in group G1, G2 and G3 when compared with control negative and positive groups.

Boonjaraspinyo et al. (2009) show the activities of serum ALT, ALP, and concentration of direct bilirubin. The serum markers (ALT, ALP) in the turmeric group remained within normal levels. Serum ALT levels increased about five- to sixfold after hamsters were administered nitrosodimethylamine and two- to threefold after infection when compared with values in the uninfected control and in that administered turmeric alone. There was a significant decrease in serum ALT in the group of nitrosodimethylamine+turmiric at 1 month. Decreased inflammatory cells led to decreased serum in ALT and decreased direct bilirubin levels in all groups treated with a turmeric diet. This result agrees with previous reports that the curcumin in turmeric reduces inflammation in many types of diseases (Yadav et al. 2009). Moreover, turmeric decreases liver 
detoxification, leading to a reduction of toxic metabolite products (Choi et al. 2008; Sugiyama et al. 2006; Surh and Chun 2007).

Table (4): Effect of turmeric on liver function in rats after 6 weeks.

\begin{tabular}{||c|c|c|c||}
\hline Groups & $\begin{array}{c}\text { ALT } \\
(\boldsymbol{\mu} / \mathbf{m l})\end{array}$ & $\begin{array}{c}\text { AST } \\
(\boldsymbol{\mu} / \mathbf{m l})\end{array}$ & $\begin{array}{c}\text { ALK } \\
(\boldsymbol{\mu} / \mathbf{m l})\end{array}$ \\
\hline \hline Co.(-) & $22.20^{\mathrm{b}} \pm 5.22$ & $7.20^{\mathrm{b}} \pm 1.79$ & $44.00^{\mathrm{c}} \pm 2.12$ \\
\hline Co.(+) & $40.80^{\mathrm{a}} \pm 19.21$ & $5.60^{\mathrm{a}} \pm 2.19$ & $42.20^{\mathrm{b}} \pm 2.59$ \\
\hline G1 & $43.40^{\mathrm{a}} \pm 8.85$ & $7.20^{\mathrm{a}} \pm 1.79$ & $37.40^{\mathrm{b}} \pm 3.85$ \\
\hline G2 & $48.00^{\mathrm{a}} \pm 8.09$ & $7.20^{\mathrm{a}} \pm 1.79$ & $32.80^{\mathrm{a}} \pm 2.49$ \\
\hline G3 & $31.00^{\mathrm{a}} \pm 7.65$ & $5.80^{\mathrm{a}} \pm 1.79$ & $38.60^{\mathrm{b}} \pm 5.46 \mathrm{ease}$ \\
\hline
\end{tabular}

Co (-), normal diet; Co (+) high-fat diet; G(1), high- fat diet plus turmeric (4g); G (2), high- fat diet plus turmeric $(6 \mathrm{~g}) ; \mathrm{G}(3)$, a high-fat diet plus turmeric (8 g). Values with the same letters by column indicate no significant difference $(\mathrm{p}<0.05)$ and vice versa.

\section{5- Effect of turmeric on kidney function in rats fed on a high-fat diet:}

Table (5) shows that the Effect of turmeric on kidney function in rats after 6 weeks, total protein and creatinine ratio gave significant increase in G1, G2 and G3 when compared with control negative and positive groups, however uric acid and urea gave significant decrease in groups G2 and G3 when compared with Co. (+)., also found the significant increase in both albumin and bilirubin in G 3 when compared with control negative and positive groups.

Boonjaraspinyo et al. (2009) demonstrated that all of the groups that were administered turmeric. The serum direct bilirubin level (which was lower in groups given a turmeric diet than in the untreated groups) shows that turmeric enhanced bile flow and biliary contraction. Serum direct bilirubin levels in the turmeric, nitrosodimethylamine and nitrosodimethylamine+turmeric groups remained within normal levels. Serum direct bilirubin levels increased about two- to eightfold after infection when compared with the uninfected control groups. The antiinflammatory property of turmeric was obviously demonstrated by the reduction of inflammatory cells in hepatic tissue compared with the 
untreated group at both 30- and 60-day time periods. Decreased inflammatory cells led to decreased direct bilirubin levels in all groups treated with a turmeric diet. This result agrees with previous reports that the curcumin in turmeric reduces inflammation in many types of diseases (Yadav et al., 2009), including liver diseases and toxicity from CCl4 (Reyes-Gordillo et al., 2008) by inhibiting cyclooxygenase-2, lipoxygenase, (Unnikrishnan and Rao 1995; Sreejayan and Rao 1994; Menon and Sudheer 2007; Pae et al., 2008). Moreover, Boonjaraspinyo et al. (2009) show the property of turmeric to enhance bile flow and gall bladder contraction through decreased direct bilirubin level, a result which is supported by Deters et al. (2000).

Table (5): Effect of turmeric on kidney function in rats after 6 weeks.

\begin{tabular}{||c|c|c|c|c|c|c||}
\hline Groups & T.P (mg/dl) & $\begin{array}{c}\text { Creat. } \\
(\mathbf{m g} / \mathbf{d l})\end{array}$ & $\begin{array}{c}\text { Urea } \\
(\mathbf{m g} / \mathbf{d l})\end{array}$ & $\begin{array}{c}\text { U.A. } \\
(\mathbf{m g} / \mathbf{d l})\end{array}$ & BIL. (mg/dl) & ALB. (mg/dl) \\
\hline \hline Co.(-) & $5.58^{\mathrm{c}} \pm 1.64$ & $0.63^{\mathrm{b}} \pm 0.08$ & $26.00^{\mathrm{b}} \pm 2.24$ & $3.36^{\mathrm{c}} \pm 0.26$ & $0.52^{\mathrm{c}} \pm 0.02$ & $3.84^{\mathrm{c}} \pm 0.38$ \\
\hline Co.(+) & $5.96^{\mathrm{b}} \pm 0.90$ & $0.48^{\mathrm{b}} \pm 0.06$ & $24.60^{\mathrm{b}} \pm 4.56$ & $3.40^{\mathrm{ab}} \pm 0.64$ & $0.52^{\mathrm{b}} \pm 0.02$ & $3.68^{\mathrm{ab}} \pm 0.75$ \\
\hline G1 & $7.20^{\mathrm{b}} \pm 0.57$ & $0.71^{\mathrm{b}} \pm 0.23$ & $30.00^{\mathrm{b}} \pm 7.04$ & $5.60^{\mathrm{a}} \pm 0.81$ & $0.51^{\mathrm{ab}} \pm 0.01$ & $3.28^{\mathrm{ab}} \pm 1.65$ \\
\hline $\mathbf{G 2}$ & $7.10^{\mathrm{a}} \pm 0.44$ & $0.66^{\mathrm{ab}} \pm 0.09$ & $22.40^{\mathrm{a}} \pm 4.51$ & $3.09^{\mathrm{ab}} \pm 0.91$ & $0.55^{\mathrm{a}} \pm 0.06$ & $4.10^{\mathrm{a}} \pm 0.14$ \\
\hline $\mathbf{G 3}$ & $6.10^{\mathrm{ab}} \pm 0.90$ & $0.81^{\mathrm{b}} \pm 0.12$ & $18.40^{\mathrm{ab}} \pm 2.88$ & $3.08^{\mathrm{ab}} \pm 0.51$ & $0.53^{\mathrm{ab}} \pm 0.03$ & $3.92^{\mathrm{ab}} \pm 0.63$ \\
\hline
\end{tabular}

Co (-), normal diet; Co (+) high-fat diet; G(1), high- fat diet plus turmeric (4g); G (2), high- fat diet plus turmeric $(6 \mathrm{~g}) ; \mathrm{G}(3)$, a high-fat diet plus turmeric (8 g). Values with the same letters by column indicate no significant difference $(\mathrm{p}<0.05)$ and vice versa.

\section{Histopathological effects:}

\section{1- Morphologic changes of rat heart stained with hematoxylin and eosin:}

Representative heart sections stained with hematoxylin and eosin in each group are shown in Figure (1:5) the heart in the control rat of group Co. (-) (Fig. 1) showed no histopathological alteration and the normal histological structure of the myocardium. Heart of rat in group Co. (+) (Fig.2) revealed intermyocardial oedema deposition of fat in pericardium with inflammatory cells infiltration, while in group 1 (Fig.3) slight 
intermuscular edema. On the other hand, the heart of rats in group 2 and group 3 (Fig.4and 5) showed histopathological alteration and the normal histological structure of the myocardium. The morphologic features of the heart in the rats of groups 2 and 3 were close to that of the control rats group Co. (-), which indicated a similar preventive effect of turmeric against hyperlipidemia in this experimental model. Also, agreed with a previous report that turmeric has no toxic effect in hamster models (Kaewsamut et al. 2007).

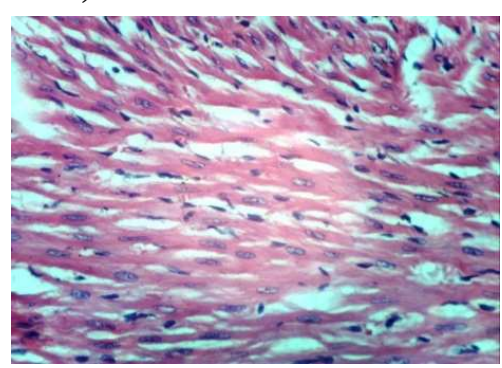

Fig. (1): Heart of rat from group Co.(-) showing no histopathological changes.

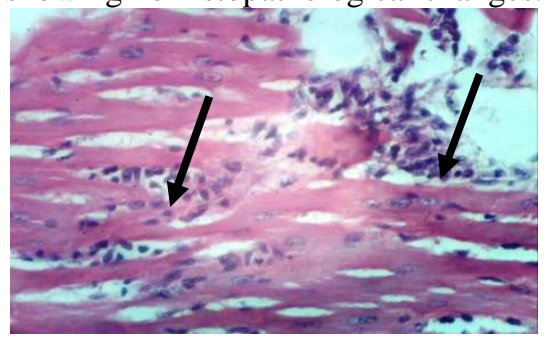

Fig. (3): Heart of rat from group 1 showing focal myocarditis.

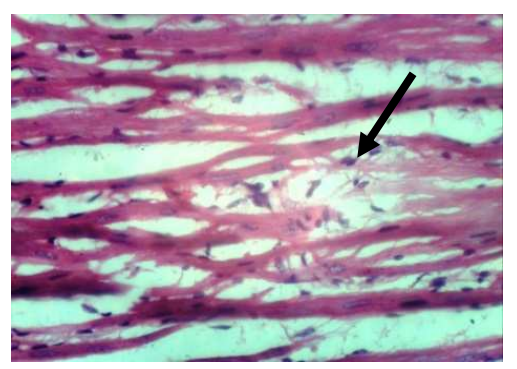

Fig. (2): Heart of rat from group Co. (+) showing intermyocardialoedema

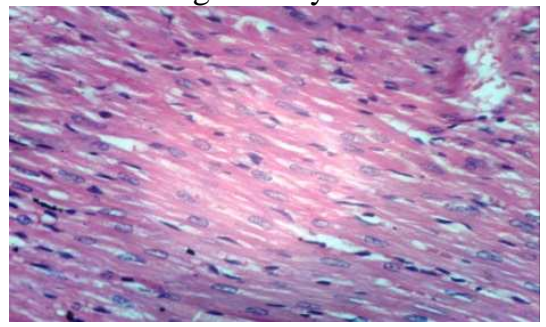

Fig. (4): Heart of rat from group 2 showing no histopathological changes

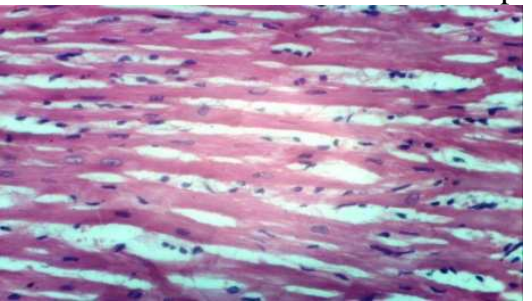

Fig. (5): Heart of rat from group 3 showing no histopathological changes.

Figure (1:5). Morphologic changes of rat heart stained by hematoxylin and eosin using a light microscope(H \& E X 400). Co. (-) rat fed standard diet (control), Co. (+) highfat diet; G (1), high-fat diet plus turmeric (4g); G (2), high-fat diet plus turmeric (6g);G (3), high-fat diet plus turmeric (8g). 


\section{2- Morphologic changes of rat liver stained with hematoxylin and eosin:}

Representative liver sections stained with hematoxylin and eosin in each group are shown in Figure (6:10). The liver in the control rat of group Co. (-) (Fig. 6) showing the normal histological structure of hepatic lobule. Liver of rat in group Co (+) (Fig.7) showing hyperplasia of the epithelial lining bile duct and thickening in its wall. Result in group 1 (Fig.8) showing slight vacuolization of hepatocytes. On the other hand, the liver of rats in group 2 (Fig.9) Showing Kupffer cells activation and cytoplasmic vacuolization of hepatocytes, group 3 (Fig.10) showed slight activation of Kupffer cells. The morphologic features of the liver in the rats of $\mathrm{G} 2$ and $\mathrm{G}$ 3 were closed to that of the control rats group Co. (-), which indicated a similar preventive effect of turmeric in this experimental model. The histopathological results showed that turmeric has no toxic side effects in normal hamsters; this was supported by the liver function test results ( Boonjaraspinyo et al. 2009).

Shao et al. (2012) examined histological changes in the liver of each group of mice. HFD consumption increased liver lipid content, demonstrated by both $\mathrm{H} \& \mathrm{E}$ staining.In the curcumin group, however, the effect of HFD on the elevation of lipid content was blocked. The effect of HFD on macrophage infiltration was also blocked by curcumin consumption.In this chronic HFD mouse model, although the liver weight was not significantly increased, intra-hepatic lipid content was increased more than 6 fold, consistent with the observation by H\&E. Curcumin significantly reduced liver weight and prevented the effect of HFD on rising intra-hepatic lipid content. 


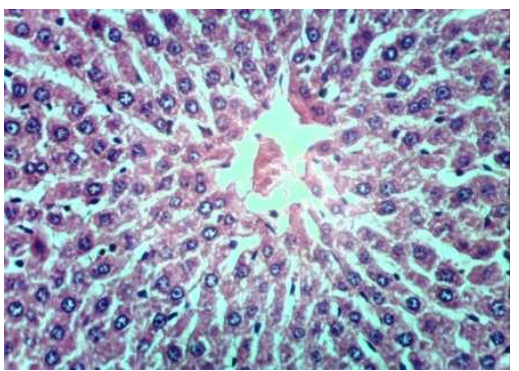

Fig. (6): Liver of rat from group Co. (-) showing the normal histological structure of hepatic

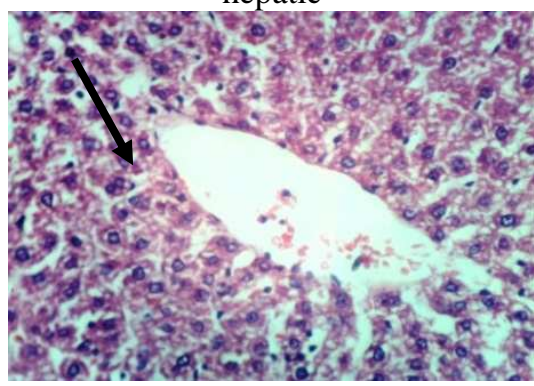

Fig. (8): Liver of rat from group 1 showing activation of Kupffer cells.

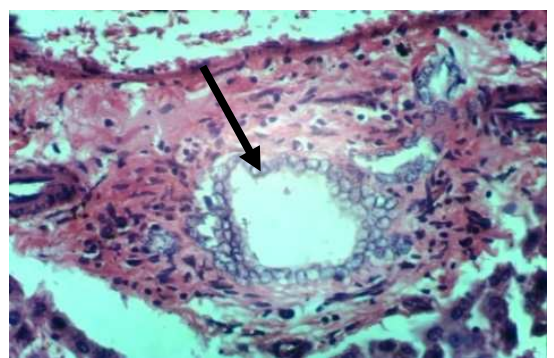

Fig. (7): Liver of rat from group Co. (+) showing hyperplasia of lobule.epithelial lining bile duct and thickening in its wall.

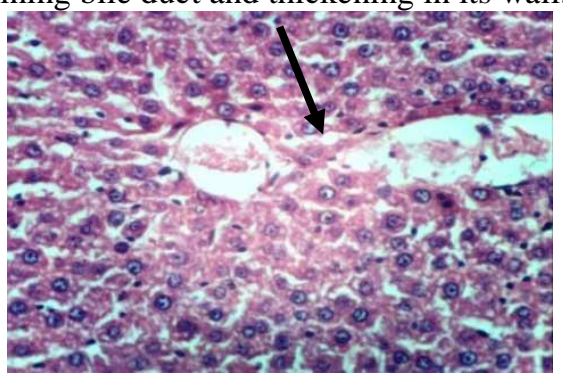

Fig. (9): Liver of rat from group 2 showing slightly slight vacuolization of hepatocytes

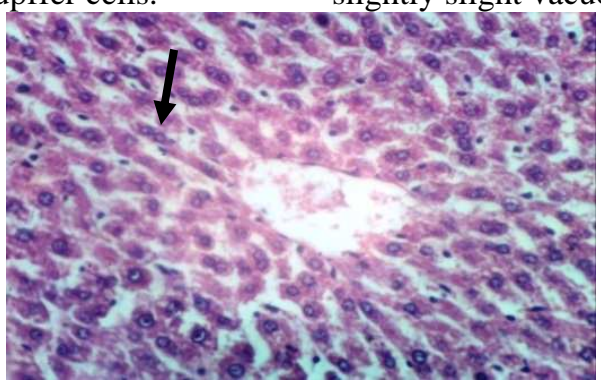

Fig. (10): Liver of rat from group 3 showing slight Activationn of Kupffer cells

Figure (6:10). Morphologic changes of rat heart stained by hematoxylin and eosin using a light microscope (H \& E X 400).Co. (-) rat fed standard diet (control), Co. (+) highfat diet; G (1), high-fat diet plus turmeric (4g); G (2), high-fat diet plus turmeric (6);G (3), high-fat diet plus turmeric $(8 \mathrm{~g})$.

\section{3- Morphologic changes of rat kidney stained with hematoxylin and eosin:}

Representative kidney sections stained with hematoxylin and eosin in each group are shown in Figure (11:15), kidney of rat in group Co. (+) (Fig.12) showing distension of Bowman's space and focal tubular necrosis 
associated with inflammatory cells infiltration, while group 1 (Fig.12) showing congestion of glomerular tufts, the kidney in the control rat of group Co. (-) (Fig. 11) showing the normal histological structure of renal parenchyma, found a similar result in the experimental groups (Fig.14:15) the morphologic features of kidney in the rats of group 2 and 3 were closed to that of the control rats group Co. (-), which indicated a similar preventive effect of turmeric. The histopathology was similar to previous reports

\section{(Thamavit et al. 1987; Boonmars et al. 2007; Boonmars et al. 2008).}

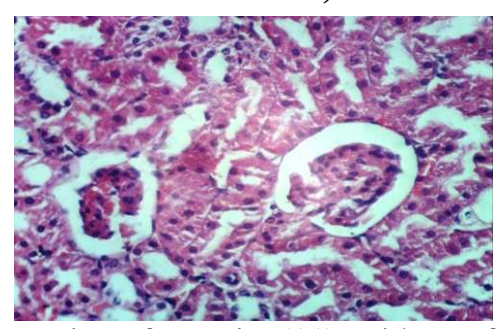

Distension of

Fig. (11): Kidney of rat

from group Co.(-) showing the normal ahistological structure of renal parenchyma

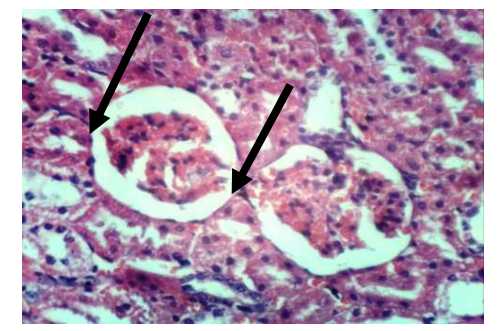

Fig. (13): Kidney of rat from group 1 showing congestion of glomerular tufts.

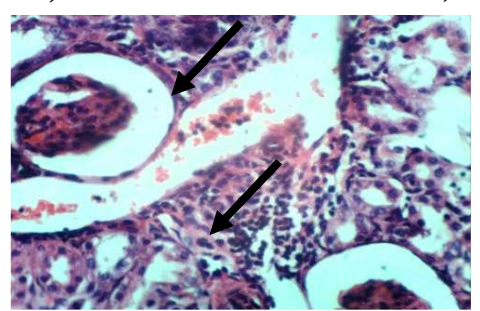

Fig. (12): Kidney of rat from group Co.(+) showing Bowman's space and focal tubular necrosis associated with inflammatory cells infiltration

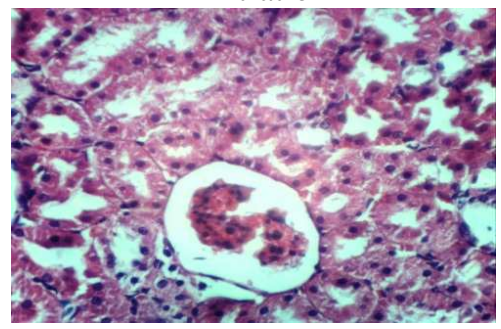

Fig. (14): Kidney of rat from group 2 showing normal renal parenchyma.

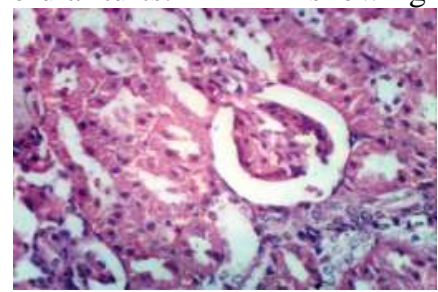

Fig. (15): Kidney of rat from group 3 showing no histopathological changes.

Figure (11:15). Morphologic changes of rat heart stained by hematoxylin and eosin using a light microscope (H \& E X 400).Co. (-) rat fed standard diet (control), Co. (+) high-fat diet; G (1), high-fat diet plus turmeric (4g); G (2), high-fat diet plus turmeric $(6 \mathrm{~g}) ; \mathbf{G}(3)$, high-fat diet plus turmeric (8g). 


\section{CONCLUSION}

This study shows that curcumin improves insulin level, glucose disposal, and blocks obesity during HFD consumption.our observations confirm that curcumin reduces total cholesterol, triglyceride and LDL cholesterol levels. There is also a tendency that the higher of curcumin dose, the higher its lowering effect on LDL cholesterol level, such as the moderate-dose curcumin. This study demonstrates a tendency of high-dose curcumin to increase the HDL cholesterol level.

\section{REFFERANCES}

- Aggarwal BB, Kumar A, and Bharti AC. (2003): Anticancer potential of curcumin: preclinical and clinical studies. Anticancer Res. 2003; 23(1A): 363398.

- AIN. (1993): American Institute of Nutrition. Purified diet for laboratory Rodent, Final Report. J. Nutr. 123:1939-1951.

- Alappat L. and Awad AB (2010): Curcumin and obesity: evidence and mechanisms.Nutr Rev 68: 729-738.

- Alwi I, Santoso T, Suyono S, Sutrisna B. and Suyatna F, (2008): The Effect of Curcumin on Lipid Level in Patients with Acute Coronary Syndrome. J Intern Med. 40: 201-212.

- Amin F, Islam N, Anila N, and Gilani AH. (2015): Clinical efficacy of the coadministration of turmeric and black seeds (Kalongi) in metabolic syndrome - a double-blind randomized controlled trial - TAK-MetS trial. Complement Ther Med. 23:165-174. doi: 10.1016/j.ctim..01.008. [PubMed] [CrossRef] [Google Scholar].

- Babu PS, , and Srinivasan K. (1997): Hypolipidemic action of curcumin, the active principle of turmeric (Curcuma longa) in streptozotocin-induced diabetic rats. Mol Cell Biochem. 166 (1-2):16975.

- Bancraft, I. D. (1975): Histochemical techniques $2^{\text {nd }}$ ed. Butter Worths, London and Boston PP. 86-87.

- Barnes PJ (2009): Role of HDAC2 in the pathophysiology of COPD. Annu Rev Physiol 71: 451-464.

- Bereswill S, Munoz M, Fischer A, Plickert R. and Haag LM, et al. (2010): Antiinflammatory effects of resveratrol, curcumin and simvastatin in acute small intestinal inflammation. PLoS One 5: e15099. 
- Bharti AC, Donato N, Singh S, and Aggarwal BB. (2003): Curcumin (diferuloylmethane) down regulates the constitutive activation of nuclear factor kappa B and IkappaBalpha kinase in human multiple myeloma cells, leading to suppression of proliferation and induction of apoptosis. Blood, 101(3): 10531062.

- Boonjaraspinyo S, BoonmarsT, Aromdee C,Srisawangwong T, Kaewsamut B, and Pinlaor S.(2009): Turmeric reduces inflammatory cells in hamster opisthorchiasis. Parasitol ResSpringer-Verlag.DOI 10.1007/s00436-009-1553-3.

- Boonmars T, Srirach P, Kaewsamut B, Srisawangwong T, Pinlaor S, Pinlaor P, Yongvanit P, and Sithithaworn P (2008): Apoptosis-related gene expression in hamster opisthorchiasis post praziquantel treatment. Parasitol Res 102:447-455.

- Boonmars T, Srisawangwong T, Srirach P, Kaewsamut B, Pinlaor S, , and Sithithaworn $\mathbf{P}$ (2007): Apoptosis-related gene expressions in hamsters reinfected with Opisthorchisviverriniand re-treated with praziquantel. Parasitol Res 102:57-62.

- BratmanS, and Girman AM. (2003): Mosby's handbook of herbs and supplements and their therapeutic uses. Page 502503, Mosby Health Gate, St. Louis.

- Chan WH, Wu CC, and Yu JS. (2003): Curcumin inhibits UV-induced oxidative stress and apoptotic biochemical changes in human epidermoid carcinoma A431 cells. J. Cell Biochem.; 90: 327-338.

- Chapman, D. G.; Castilla, R. and Campbell, J. A. (1959): Evaluation of protein in food. Method for the determination of protein efficiency ratio. Can .J. Biochem. Phsiol., 1: 679- 686.

- Cheng AL, Hsu CH, Lin JK, Hsu MM, Ho YF, Shen TS, Ko JY, Lin JT, Lin BR, Ming-, and Shiang W, et al. (2001): Phase I clinical trial of curcumin, a chemopreventive agent, in patients with high-risk or pre-malignant lesions. Anticancer Res. ;21:2895-2900. [PubMed] [Google Scholar].

- Choi H, Chun YS, Shin YJ, Ye SK, Kim MS, and Park JW (2008): Curcumin attenuates cytochrome $\mathrm{P} 450$ induction in response to $2,3,7,8$ tetrachlorodibenzo-p-dioxin by ROS-dependently degrading AhR and ARNT. Cancer Sci 99:2518-2524.

- Chuengsamarn S, Rattanamongkolgul S, Phonrat B, Tungtrongchitr R, and Jirawatnotai S. (2014): Reduction of atherogenic risk in patients with type 2 
diabetes by curcuminoid extract: a randomized controlled trial. J NutrBiochem. 2014;25:144-150. DOI: 10.1016/j.jnutbio.2013.09.013. [PubMed] [CrossRef] [Google Scholar].

- Deters M, Siegers C, Hänsel W, Schneider KP, and Hennighausen G (2000): Influence of curcumin on cyclosporin induced reduction of biliary bilirubin and cholesterol excretion and on biliary excretion of cyclosporin and its metabolites. Planta Med 66:429-434.

- Drury, R. A. and Wallington, E. A. (1980): Carlton's Histological Technique. $5^{\text {th }}$ ed. Oxford University.

- Fendewaid, W. T. (1972): Determination of HDL. Clin. Chem. 18:499-503.

- Fossati, P.; Prencipe, L.and Berti, G.(1980): Enzymatic colorimetric method of determination of uric acid in serum. Clin.Chem., 26(2),227-237.

- Ghada, Z. A., and Soliman (2005): Effect of Curcumin, Mixture of Curcumin and Piperine and Curcum (Turmeric) on Lipid Profile of Normal and Hyperlipidemic Rats The Egyptian Journal of Hospital Medicine. 21, 145 - 161.

- Goel A, Kunnumakkara AB, and Aggarwal B B. (2008): Curcumin as "Curcumin": from kitchen to clinic. BiochemPharmacol. 2008;75:787-809. DOI: 10.1016/j.bcp..08.016. [PubMed] [CrossRef] [Google Scholar].

- Gordon, T. and Amer, M. (1977): Determination of HDL. J. Med. 63:707-709.

- Henry, R. J. (1964): Colormeteric method to determination serum total protein. Clin. Chem. 7: 181-245.

- Hulbron G, Aubert R, Bourgeois F, and Lemonnier D. (1982): Early cholesterol feeding: Are there long-term effects in the rats?. J. Nut., 112: 12461305.

- Husdan,H. and Rapoport, A. (1968): Estimation of creatinine by Jaffe reaction. Clin.Chem., 14,222-228.

- Jaiswal AS, Marlow BP, Gupta N, and Narayan S (2002): Beta-cateninmediated transactivation and cell-cell adhesion pathways are important in curcumin (diferuylmethane)-induced growth arrest and apoptosis in colon cancer cells. Oncogene 21: 8414-8427.

- Jayakumar V, Ahmed SS, and Ebenezar KK. (2016): Multivariate analysis and molecular interaction of curcumin with PPARgamma in high fructose dietinduced insulin resistance in rats. Spring. 5:1732. DOI: 10.1186/s40064-0163364-1. [PMC free article] [PubMed] [CrossRef] [Google Scholar]. 
=Efficacy and safety of turmeric in lowering blood lipid levels and glucose in rats Fed High-Fat Diets

- Kaewsamut B, Pinlaor S, Boonmars T, Srisawangwong T, and Yongvanit P (2007): Effect of curcumin on the inducible nitric oxide synthase (iNOS) and antioxidant enzyme expression in hamsters infected with Opisthorchisviverrini. Southeast Asian J Trop Med. Publ. Health 38:66-73.

- Kahlone TS, Chow FI, Irving DW, and Sayre RN. (1997): Cholesterol response and fatty streak formation in hamsters fed two levels of saturated fat and various levels of cholesterol. J. Nut. Res., 17: 16931707.

- Kang Q, , and Chen A. (2009): Curcumin suppresses expression of low-density lipoprotein (LDL) receptor, leading to the inhibition of LDL-induced activation of hepatic stellate cells. Br. J. Pharmacol. 2009;157:1354-1367. doi: 10.1111/j.1476-5381.2009.00261.x. [PMC free article] [PubMed] [CrossRef] [Google Scholar].

- Kunnumakkara AB, Bordoloi D, Padmavathi G, Monisha J, Roy NK, Prasad S, , and Aggarwal BB. (2016): Curcumin, the golden nutraceutical: multitargeting for multiple chronic diseases. $\mathrm{Br} \quad \mathrm{J}$ Pharmacol. 10.1111/bph.1362. [PMC free article] [PubMed].

- Lee, R. and Nieman, D. (1996): Nutritional Assessment; $2^{\text {nd }}$ ed Mosby Missouri, USA.

- Li ZY, Ding LL, Li JM, Xu BL, Yang L, Bi KS, and Wang ZT. (2015): HNMR and MS-based metabolomics study of the intervention effect of curcumin on hyperlipidemia mice induced by high-fat diet. PLoS One. ;10:e0120950. DOI: 10.1371/journal.pone.0120950. [PMC free article] [PubMed] [CrossRef] [Google Scholar].

- Maithili KarpagaSelvi N, Sridhar MG, Swaminathan RP and Sripradha R. (2015): Efficacy of turmeric as adjuvant therapy in type 2 diabetic patients. Indian J ClinBiochem. 2015;30:180-186. DOI: 10.1007/s12291-0140436-2. [PMC free article] [PubMed] [CrossRef] [Google Scholar].

- Maithilikarpagaselvi N, Sridhar MG, Swaminathan RP, Sripradha R, and Badhe B. (2016): Curcumin inhibits hyperlipidemia and hepatic fat accumulation in high-fructose-fed male Wistar rats. Pharm Biol. 2016;54:28572863. DOI: 10.1080/13880209.1187179. [PubMed] [CrossRef] [Google Scholar].

- Menon VP, and Sudheer AR (2007): Antioxidant and anti-inflammatory properties of curcumin. AdvExp Med Biol 595:105-125. 
- Mesa MD, Aguilera CM, RamirezTortosa CL, Ramirez-Tortosa MC, Quiles JL, Baró L, Martínez de Victoria E, and Gil A. (2003): Oral administration of a turmeric extract inhibits erythrocyte and liver microsome membrane oxidation in rabbits fed with an atherogenic diet. Nutrition; 19(9): 800-804.

- Mirzabeigi P, Mohammadpour AH, Salarifar M, Gholami K, Mojtahedzadeh M, and Javadi MR. (2015): The effect of Curcumin on some of traditional and non-traditional cardiovascular risk factors: a pilot randomized, double-blind, Placebo-controlled Trial. Iran J Pharm Res. ;14:479-486. [PMC free article] [PubMed] [Google Scholar].

- Mohammadi A, Sahebkar A, Iranshahi M, Amini M, Khojasteh R Ghayour-Mobarhan M, and Ferns GA.(2013): Effects of supplementation with curcuminoids on dyslipidemia in obese patients: a randomized crossover trial. PhytotherRes. ;27:374-379. DOI: 10.1002/ptr.4715. [PubMed] [CrossRef] [Google Scholar].

- Morimoto T, Sunagawa Y, Kawamura T, Takaya T, and Wada H, et al. (2008): The dietary compound curcumin inhibits p300 histone acetyltransferase activity and prevents heart failure in rats. J Clin Invest 118: 868-878.

- Mukhopadhyay A, Banerjee S, Stafford LJ, Xia C, and Liu M, et al. (2002): Curcumin-induced suppression of cell proliferation correlates with downregulation of cyclin D1 expression and CDK4-mediated retinoblastoma protein phosphorylation. Oncogene 21: 8852-8861.

- Murray RR, Granner DK, Mayes PA, and Rodwell VW. (2000): Harpers'Biochemistry, chapters 52 \& 60.

- Musunuru K. (2010): Atherogenic dyslipidemia: cardiovascular risk and dietary intervention. Lipids. ;45:907-914. doi: 10.1007/s11745-010-3408-1. [PMC free article] [PubMed] [CrossRef] [Google Scholar].

- Neerati P, Devde R, and Gangi AK. (2014): Evaluation of the effect of curcumin capsules on glyburide therapy in patients with type-2 diabetes mellitus (2014): PhytotherRes. ;28:1796-1800. DOI: 10.1002/ptr.5201. [PubMed] [CrossRef] [Google Scholar].

- NIHP. (1987): National Institute of Health Publication. Detection, Evaluation and Treatment of High Cholesterol in Adult; No.88:292.

- Pae HO, Jeong SO, Kim HS, Kim SH, Song YS, Kim SK, Chai KY, and Chung HT (2008): Dimethoxycurcumin, a synthetic curcumin analogue with higher metabolic stability, inhibits NO production, inducible NO synthase 
=Efficacy and safety of turmeric in lowering blood lipid levels and glucose in rats Fed High-Fat Diets

expression and NF-kappaB activation in RAW264.7 macrophages activated with LPS. MolNutr Food Res 52:1082-1091.

- Patton C.J. and Crouch, S.R. (1977): Enzymatic colorimetric method to determine urea in serum. Anal.Chem., 49,464-469.

- Phan TT, See P, Lee ST, and Chan SY. (2001): Protective effects of curcumin against oxidative damage on skin cells in vitro: its implication for wound healing. J. Trauma; 51(5): 927-931.

- Pulido-Moran M, Moreno-Fernandez J, Ramirez-Tortosa C, and RamirezTortosa M. (2016): Curcumin and health. Molecules. 2016;21:264. DOI: 10.3390/molecules21030264. [PMC free article] [PubMed] [CrossRef] [Google Scholar].

- Quiles JL, Mesa MD, Ramirez-Tortosa CL, Aguilera CM, Battino M, Gil A, and Ramirez-Tortosa MC. (2002): Curcuma longa extract supplementation reduces oxidative stress and attenuates aortic fatty acid streak development in rabbits. Arterioscler.. Biol.; 22(7): 1225-1231. ThrombVasc

- Rahimi HR, Mohammadpour AH, Dastani M, Jaafari MR, Abnous K, GhayourMobarhan M, and Kazemi OR. (2016): The effect of nano-curcumin on HbA1c, fasting blood glucose, and lipid profile in diabetic subjects: a randomized clinical trial. Avicenna J Phytomed. 2016;6:567-577. [PMC free article] [PubMed] [Google Scholar].

- Rahmani S, Asgary S, Askari G, Keshvari M, Hatamipour M, Feizi A, and Sahebkar A.(2016): Treatment of non-alcoholic fatty liver disease with curcumin: a randomized placebo-controlled trial. Phytother Res. 30:1540-1548. DOI: 10.1002/ptr.5659. [PubMed] [CrossRef] [Google Scholar].

- Ramirez-Boscá A, Soler A, Gutierrez MAC, Álvarez JL, and Almagro EQ. (1995): Antioxidant curcuma extracts decrease the blood lipid peroxide levels of human subjects. Age; 18: 167-169.

- Ramirez-Tortosa MC, Mesa MD, Aguilera MC, Quiles JL, Baró L, Martínez de Victoria E, and Gil A. (1999): Oral administration of a turmeric extract inhibits LDL oxidation and has hypocholesterolemic effects in rabbits with experimental atherosclerosis. Atherosclerosis; 147(2): 371-378.

- Ramsewak RS, DeWitt DL, and Nair MG. (2000): Cytotoxicity, antioxidant and anti-inflammatory activities of curcumins IIII from Curcuma longa. Phytomedicine; 7(4): 303-308. 
- Reitman, S. and Frankel, S. (1957): Acalorimetric method for the determination of serum glutamic-oxaloacetic and glutamic -pyrovate transaminase. Am. J. Clin. Path.pp 28-56.

- Reyes-Gordillo K, Segovia J, Shibayama M, Tsutsumi V, Vergara P, Moreno MG, and Muriel P (2008): Curcumin prevents and reverses cirrhosis induced by bile duct obstruction or $\mathrm{CCl} 4$ in rats: role of TGF-beta modulation and oxidative stress. FundamClinPharmacol 22:417-427.

- Sahebkar A, Chew GT, and Watts GF.(2014): Recent advances in pharmacotherapy for hypertriglyceridemia. Prog Lipid Res. ;56:47-66. DOI: 10.1016/j.plipres.07.002. [PubMed] [CrossRef] [Google Schola r].

- Sahebkar A. (2013): Systematic review and meta-analysis of randomized controlled trials investigating the effects of curcumin on blood lipid levels. Clin Nutr. ;33:406-414. DOI: 10.1016/j.clnu..09.012. [PubMed] [CrossRef] [Google Scholar].

- Sahebkar ${ }^{1}$ A.( 2014):Curcuminoids for the management of hypertriglyceridaemia. Nat Rev Cardiol.; 11:123. doi: 10.1038/nrcardio.140c1. [PubMed] [CrossRef] [Google Scholar].

- Sahebkar ${ }^{2}$ A.(2014): Low-density lipoprotein is a potential target for curcumin: novel mechanistic insights. Basic ClinPharmacolToxicol.;114:437-438. doi: 10.1111/bcpt.12212. [PubMed] [CrossRef] [Google Scholar].

- Saleheen D, Ali SA, Ashfaq K, Siddiqui AA, Agha A, and Yasinzai MM. (2002): Latent activity of curcumin against leishmaniasis in vitro. Biol. Pharm. Bull.; 25(3): 386-389.

- Sérougne C, Catherine F, Jacqueleni F, Tahar H, Catherine B, and Andrzej M. (1995): Hypercholesterolemia induced by cholesterol or cysteine-enriched diets are characterized by different concentrations in rats. J. Nut., 125: 35-41.

- Shao W, Yu Z, Chiang Y, Yang Y, and Chai T, et al. (2012): Curcumin Prevents High Fat Diet-Induced Insulin Resistance and Obesity via Attenuating Lipogenesis in Liver and Inflammatory Pathway in Adipocytes. PLoS ONE 7(1): e28784. DOI:10.1371/journal.pone.0028784.

- Shin SK, Ha TY, McGregor RA, and Choi MS. (2011): Long-term curcumin administration protects against atherosclerosis via hepatic regulation of lipoprotein cholesterol metabolism. Mol. Nutr. Food Res.; 55:1829-1840. DOI: 10.1002/mnfr.201100440. [PubMed] [CrossRef] [Google Scholar]. 
=Efficacy and safety of turmeric in lowering blood lipid levels and glucose in rats Fed High-Fat Diets

- Si Qin, Lifan Huang, Jiaojiao Gong, ShashaShen, Juan Huang, Hong Ren, and Huaidong Hu (2017): Efficacy and safety of turmeric and curcumin in lowering blood lipid levels in patients with cardiovascular risk factors: a metaanalysis of randomized controlled trials.Nutr J.; 16: 68.doi: 10.1186/s12937-0170293-y.

- Soare A, Weiss EP, Holloszy JO, and Fontana L. (2014): Multiple dietary supplements do not affect metabolic and cardiovascular health. Aging (Albany NY);6:149-157. DOI: 10.18632/aging.100597. [PMC free article] [PubMed] [CrossRef] [Google Scholar].

- SPSS. (1998): Statistical Package for Social Science, Computer Software; ver.10 SPSS Company. London, UK.

- Sreejayan and Rao MN. (1994): Free radical scavenging activity of curcuminoids. Arzneimittelforschung; 46: 169-171.

- Sreejayan, and Rao MN (1996): Curcuminoids as potent inhibitors of lipid peroxidation. J Pharm Pharmacol 46:1013-1016.

- Srikanth S, and Deedwania P. (2016): Management of Dyslipidemia in patients with hypertension, diabetes, and metabolic syndrome. CurrHypertens Rep.;18:76. DOI: 10.1007/s11906-016-0683-0. [PubMed] [CrossRef] [Google Scholar].

- Sugiyama T, Nagata J, Yamagishi A, Endoh K, Saito M, Yamada K, Yamada S, and Umegaki K (2006): Selective protection of curcumin against carbon tetrachloride-induced inactivation of hepatic cytochrome P450 isozymes in rats. Life Sci 78:2188-2193.

- Surh YJ, and Chun KS (2007): Cancer chemopreventive effects of curcumin. AdvExp Med Biol 595:149-172.

- Suryanarayana P, Krishnaswamy K, and Reddy GB. (2003): Effects of curcumin on galactose induced cataractogenesis in rats. Mol. Vis.; 9: 223-230.

- Thamavit W, Kongkanuntn R, Tiwawech D, and Moore MA (1987): Level of Opisthorchisinfestation and carcinogen dose-dependence of cholangiocarcinoma induction in Syrian golden hamsters. Virchows Arch B CellPatholInclMolPathol 54:52-58.

- Unnikrishnan MK, Rao MN (1995): Curcumin inhibits nitrogen dioxide induced oxidation of hemoglobin. Mol Cell Biochem 146:35-37

- Usharani P, Mateen AA, Naidu MU, Raju YS, and Chandra N. (2008): Effect of NCB-02, atorvastatin and placebo on endothelial function, oxidative 
stress and inflammatory markers in patients with type 2 diabetes mellitus: a randomized, parallel-group, placebo-controlled, 8-week study. Drugs R D.;9:243-250. DOI: 10.2165/00126839-200809040-00004. [PubMed] [CrossRef] [Google Scholar].

- Weisberg SP, Leibel R, and Tortoriello DV (2008): Dietary curcumin significantly improves obesity-associated inflammation and diabetes in mouse models of diabesity. Endocrinology 149: 3549-3558.

- Yadav VR, Suresh S, Devi K, Yadav S (2009): Novel formulation of solid lipid microparticles of curcumin for anti-angiogenic and anti-inflammatory activity for optimization of therapy of inflammatory bowel disease. J Pharm Pharmacol 61:311-321.

- Yang YS, Su YF, Yang HW, Lee YH, Chou JI, and Ueng KC. (2014): Lipidlowering effects of curcumin in patients with metabolic syndrome: a randomized, double-blind, placebo-controlled trial. Phytother Res. 2014;28:1770-1777. DOI: 10.1002/ptr.5197. [PubMed] [CrossRef] [Google Scholar].

- Young, and Pestaner. (1975): Determination of triglycerides. Bincon diagnostics, Germany.Ann. Clin..Biochem. 21:25.

- Yu Z, Shao W, Chiang Y, Foltz W, and Zhang Z, et al. (2010): Oltiprazupregulates the nuclear respiratory factor 2 alpha subunit (NRF2) antioxidant system and prevents insulin resistance and obesity induced by a high-fat diet in C57BL/6J mice. Diabetologia. 


\title{
فعالية وسلامة الكركم في خفض هستويات دهون الدم والبلوكوز \\ لدي الفئران المغذاة علي وجبات هرتفعة الدهون
}

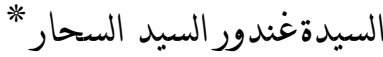

الإذص العرببي

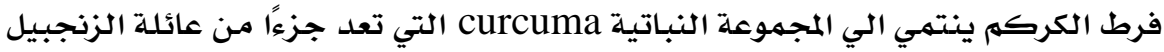

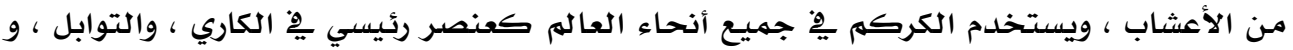

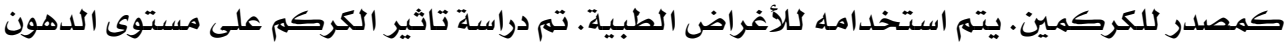

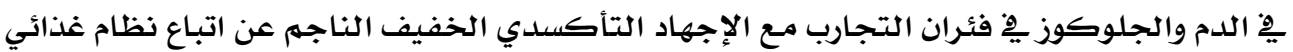

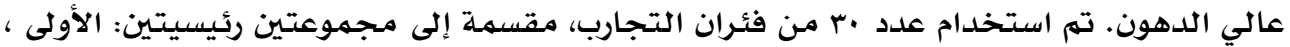

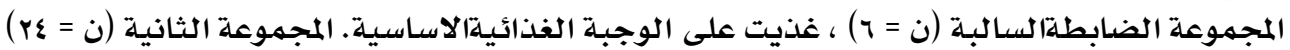

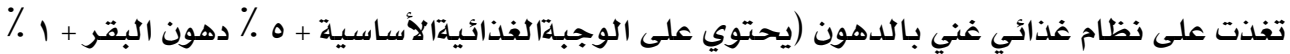

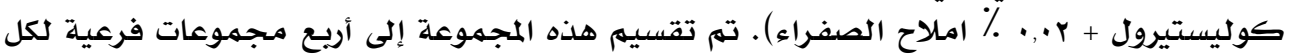

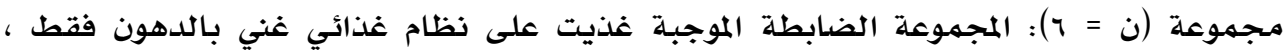

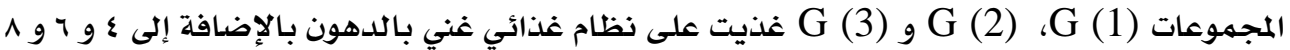

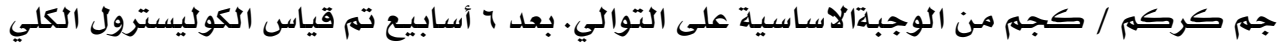

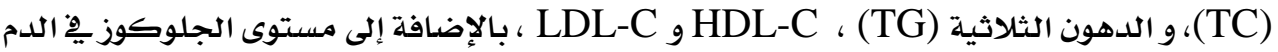

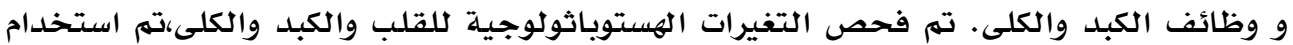

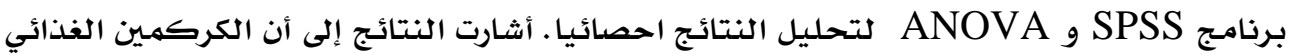

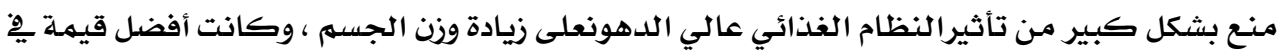

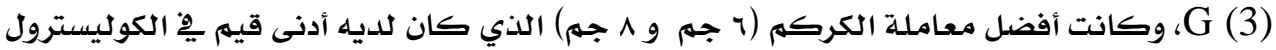

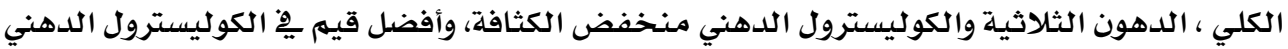

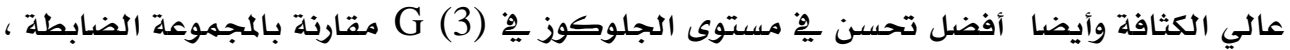

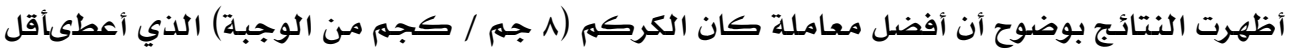

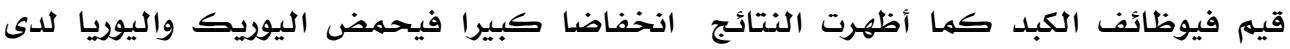

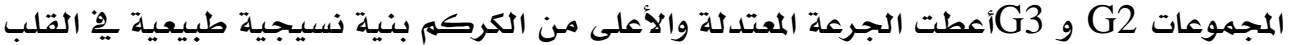

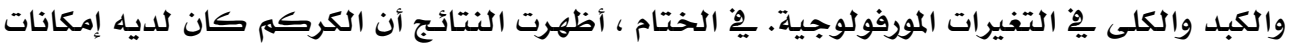

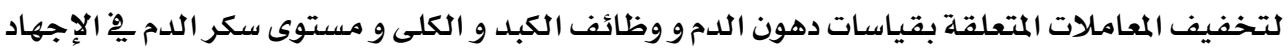

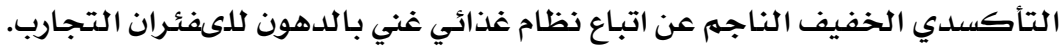

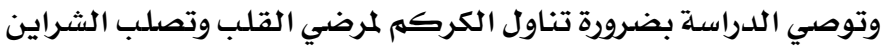

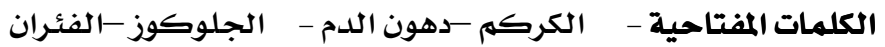

قسم الاقتصاد المنزلي - كلية التربية ألنوعيه - جامعة عين شمس - مصر 